\title{
HISTORICAL EVOLUTION OF NATURAL RESOURCE USE IN THE CENTRAL PYRENEES OF SPAIN
}

\author{
Christina Ghocarro, Rosario Fanlo, Federico Fillat, and Pedro Marin \\ Instituto Pirenaico de Ecologia \\ Apartado 64 \\ Jaca (Huesca), Spain
}

\begin{abstract}
This paper presents an overview of the evolution of the Huesca landscape with emphasis on stockbreeding activities from Paleolithic times until the present. A generalized account of changes before A.D. 1800 traces the development of the population from hunters and gatherers to stockbreeders and cultivators. After 1800, population increased and the potato and crop rotation were introduced. By the twentieth century the impacts of outmigration, new technologies, and urbanization heralded the greatest landscape changes.
\end{abstract}

RÉSUMÉ L'évolution historique de l'utilisation des ressources naturelles dans les vallées des Pyrénées centrales espagnoles. Cet article présente une vue d'ensemble de l'évolution du paysage de Huesca, en particulier l'élevage du bétail de la période paléolithique jusqu'à nos jours. Un compte-rendu général des changements que se sont produits avant 1800 ap. J.-C. suit l'évolution de la population, depuis les chasseurs et cueilleurs jusqu'aux éleveurs et cultivateurs. Après 1800, la population a augmenté et la culture de la pomme de terre ainsi que la rotation des cultures ont été introduites. Au vingtième siècle, les impacts de l'émigration, des nouvelles technologies et de l'urbanisation ont provoqué les plus grands changements de paysage.

zuSammenfassung Die historische Entwicklung der Naturressourcennutzung in den Tälern der Zentralpyrenäen, Spanien. Dieser Artikel gibt für das Huesca Gebiet einen Überblick über die Entwicklungen bezüglich der Viehzucht für den Zeitraum von der Steinzeit bis zur Gegenwart. Eine verallgemeinernde Darstellung der Veränderungen vor 1800 A.D. verfolgt den Wandel der Bevölkerung von Jägern und Sammlern zu Viehzüchtern and Landwirten. Nach 1800 stieg die Bevölkerungszahl, und als Folge wurden Kartoffelanbau sowie Wechselwirtschaft eingeführt. Das 20. Jahrhundert brachte dann die einschneidensten Landschaftsveränderungen als Folge von Abwanderung, neuen Technologien and Urbanisierung.

RESUMEN Evolución histórica de la utilización de los recursos naturales en los valles de los Pirineos Centrales españoles. Se expone revisivamente la evolución del paisaje norte de la provincia de Huesca, en el que incidió principalmente, la actividad ganadera desde el Paleolítico hasta la actualidad. Un relato general se refiere a los cambios ocurridos desde 1.800 a. de C., en que aparecen huellas del desarrollo de una población de cazadores y recolectores y más tarde ganaderos y labradores. Después de 1.800, la población incrementó y se introdujo el cultivo de la patata y la rotación de cultivos. Durante el presente s. XX, los impactos emigratorios, las nuevas tecnologias y la urbanización rigieron en buena medida, los cambios del paisaje.

\section{INTRODUGTION}

Geographically, the mountain valleys of the Spanish Central Pyrenees are self-contained, isolated entities but their historical development is closely related to that of other mountain villages on the northern slope in France and in the Ebro Valley.

These valleys have been influenced by the flow of ideas and information from France and by the possibilities of commerce and wage labor in other parts of Spain, despite a poorly developed transportation system.

Expansion to the Ebro Valley in the south was consolidated during the Christian reconquest and this led to a great expansion in the area under winter grazing. Initially the interchange of ideas and goods took place along mountain trails; the opening of roads along the valley floors provided no significant improvement. Recently, however, these villages have become completely integrated into the Spanish community.

Very few studies have been made on the historical development of the Pyrenees so that the present paper considers only the most significant episodes in the evolution of the present-day landscape. 


\section{GEOGRAPHICAL FEATURES}

The Pyrenees are about $500 \mathrm{~km}$ in length and the greatest width is about $50 \mathrm{~km}$; there are only a few summits above $3,000 \mathrm{~m}$ and glaciers, even during the Ice Ages, were never large enough to carve wide open troughs, which would have made agricultural exploitation easier. In medieval times, when there was an increase in the number of livestock, nomadic herders moved outward to other regions. Later, with the introduction of new technologies, the area of cultivated land could be increased in some instances but, in general, the initial difficulties of subsisting in narrow mountain valleys have persisted. The potential of each valley to adapt to the series of changes has depended to a certain extent on its location in the mountain chain. Figure 1 is a schematic diagram of mountains in the province of Huesca. Here it can be shown that villages located west of Mount Perdido are located in narrower valleys than those to the east, because the Axial Pyrenees, including Mount Perdido, are higher and more deeply dissected than the Inner Range.
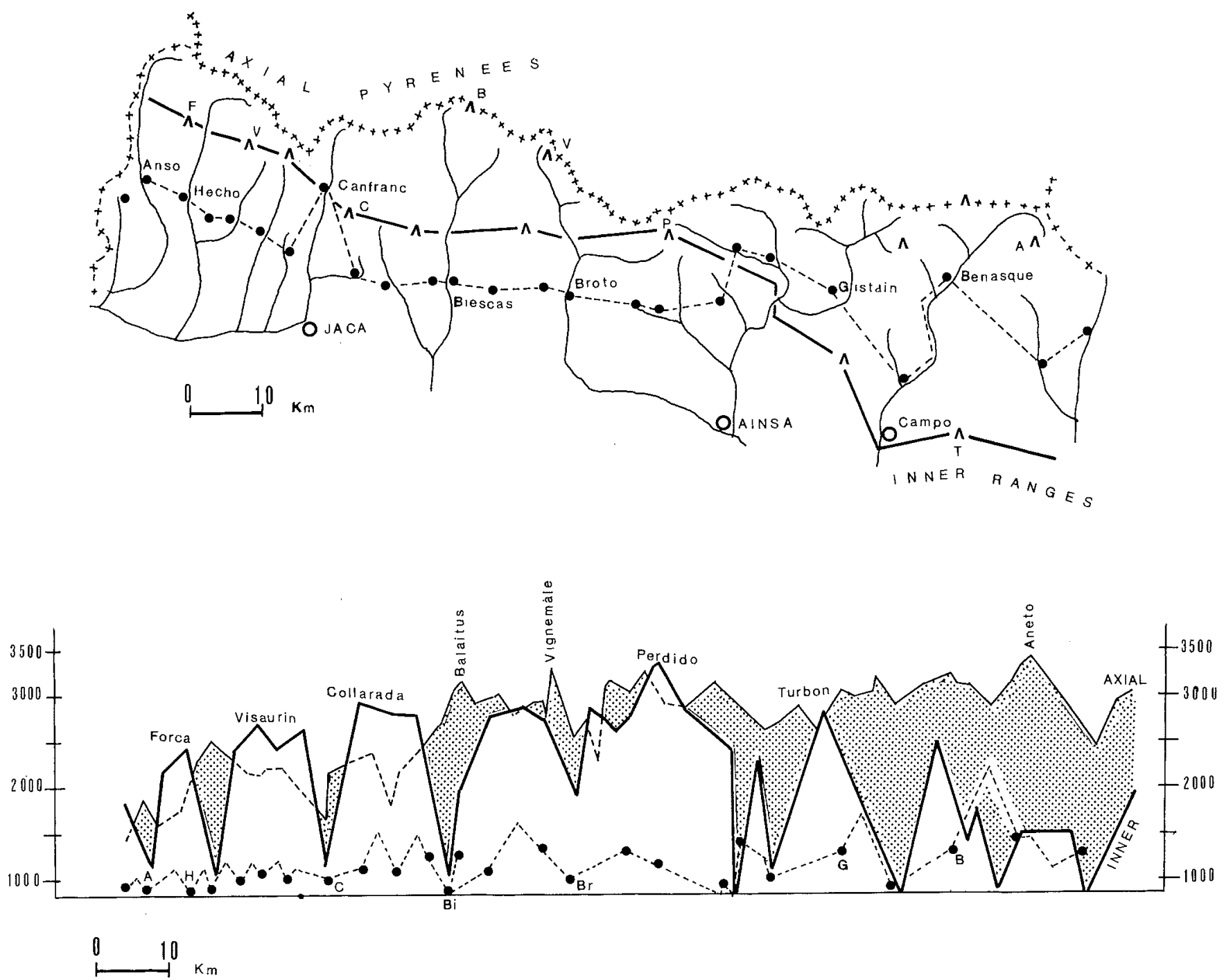

Figure 1. Comparison between the valleys to the east and west of Mount Perdido in the Pyrenees.

Key:

$x x x$ International boundary

$x-x$ Huesca provincial boundary

::::: Axial Pyrenees

$\square$ Inner ranges of the Pyrenees

The letters F, V, C, etc., on the map represent the mountain peaks, Forca, Visaurin, Collarada, etc., shown on the profile below; the towns of Anso, Hecho, etc., are indicated by initial letter on the profile which indicates also their altitude. 


\section{HISTORICAL EVOLUTION}

Two stages of land-use development can be distinguished: one, prior to 1800 , characterized by population expansion based on agriculture; and a second, following a time of demographic stabilization and maximum expansion, which was a period of recession and eventually the total abandonment of some valleys.
It is difficult to make generalizations about the evolution of landscape in the Central Pyrenees because each valley has its own peculiar history. However, despite the exceptions to the theoretical model, the trends of development are summarized in Figure 2.

\section{DEVELOPMENT BEFORE 1800}

\section{Paleolithic}

This broad prehistoric period was characterized by the existence of a scanty population with a few settlements on the most favorable, low-lying lands. Remains of these people are found in the most frequented locations, such as near Lourdes. Their main activities were harvesting wild fruits and hunting (Bahn, 1983).

\section{NEOLITHIC}

With the disappearance of the glaciers, population increases, and the beginnings of agriculture, the inhabitants exploited new areas - moving out from the valley floors to the middle slopes. A great number of archeological remains from this period have been found, including cave dwellings and megaliths. Harvesting was no longer limited to wild crops; cereals and vegetables were introduced from eastern Europe (Vicens, 1954). Stockbreeding became important, especially with the pig, an animal which can be fed kitchen leftovers and whose breeding does not require complex techniques. Later, sheep and horses were also acquired through trading with other regions (Altuna, 1972).

\section{Early Documented History}

Three pre-Roman peoples are known to have settled in the Central Pyrenees: Vascones, Iacetanos, and Ilergetes, each with different sociocultural levels. The arrival of the Romans brought about the greatest changes. Population gradually increased until the fourth century A.D. and a period of urbanization began. The cities of Jaca, Berdun, and Boltana, for example, were founded during this time. Greater economic specialization became necessary and this brought about changes in land use (Ubieto, 1981).

The development and intensification of cultivation was aided by new technology introduced by the Romans, and expansion to new lands and penetration of the forest areas continued. Cattle became important and also sheep. Stockbreeding in the mountains became more significant in relation to cultivation on the plains.

\section{Crisis in the Fourth and Fifth Centuries}

Economic and political crises at the end of the third century A.D. brought about a ruralization movement. The invasion of the Groths and defeat of Imperial Rome led to the abandonment of urban centers and the population was reduced to tribal forms of organization, similar to those at the beginning of the preceding period (Ubieto, 1981).

These events prevented further population growth and there were no significant demographic changes until the late medieval period. Agricultural methods were primitive although the total volume of production remained stable (Ubieto, 1981). A decline in the breeding of sheep and draft animals occurred due to the lack of trading and interchange; the number of cattle appears to have remained stable, and reliance on the pig expanded because of its traditional association with the earlier forms of mountain subsistence.

These conditions persisted throughout the period when the Visigoths controlled the land and into the eighth and ninth centuries. By then new political forms began to emerge as a consequence of the direct and indirect influence of the Gauls. These developments served to hold back the advances of the Moslem world to the south. It was a period when urban life began to re-emerge and economic recovery led to reoccupation of land that had been cultivated ealier and abandoned.

\section{Expansion in the Thirteenth Century}

These improved conditions stabilized; population increased; cultivation and stockbreeding developed; land at higher altitudes was utilized; and, for the first time, summer pastures above the upper levels of cultivation were developed. The role of the Church was important also, as it was through the work of the monasteries that farming techniques were revived. Commercial trading was enhanced by the establishment of markets and livestock fairs. Contacts with more distant centers across the Iberian Peninsula developed (Ubieto, 1981).

The reconquest of lands to the south was not yet sufficient to absorb the increase in population and new villages were established, even in locations with difficult access and marginal productivity. The pig was still the staple food; there was also an increase in the number of work animals used in the fields and forests where trees were felled for construction and fuelwood. Sheep were imported and used for wool production; they were grazed in summer on the high mountain pastures and in winter in the Ebro Valley. They were owned principally by aristocratic families. Cattle also became more important in the economy.

The intensity of land use and the level of prosperity achieved during this period were not achieved again until the eighteenth century (Ubieto, 1981).

\section{The Fourteenth-Century Grisis}

The wide-reaching disturbances of this period - wars, hunger, high taxes, and above all the Black Death (bubonic plague) - are well known. About 40 percent of the popula- 


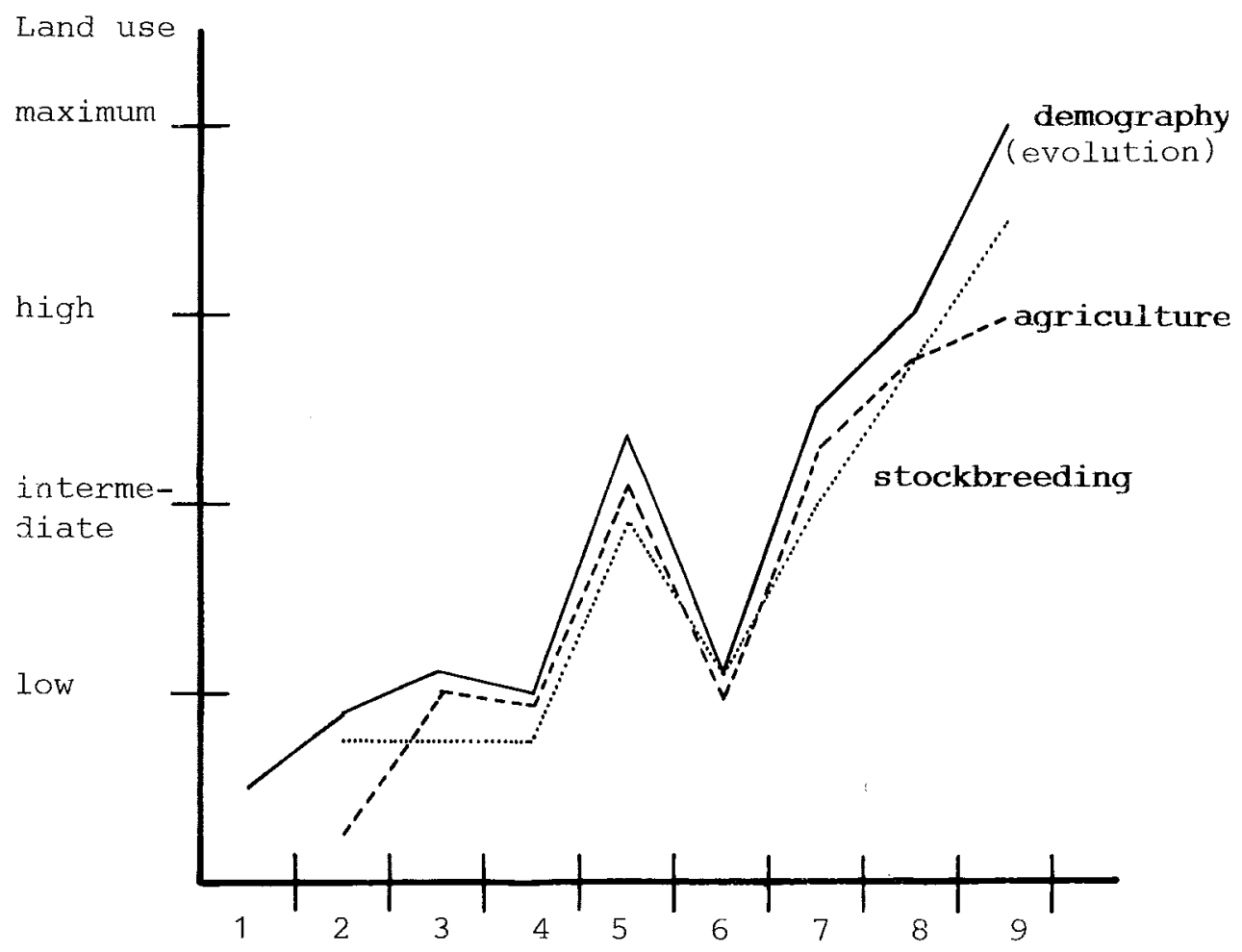

land use

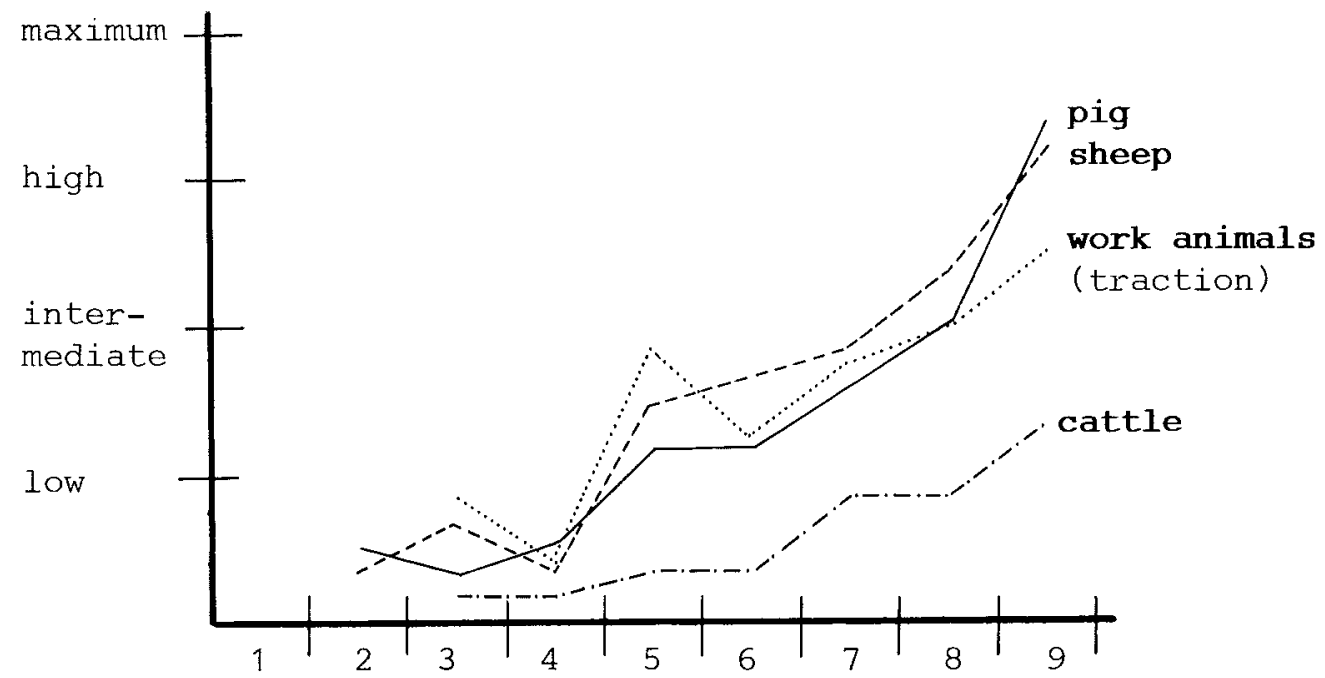

Figure 2. Demographic and agricultural trends according to the major historic periods.

Key: 1. Paleolithic

2. Neolithic

3. Early documented history

4. Fourth and fifth centuries

5. Expansion in the thirteenth century

6. Fourteenth century

7. Expansion between the fifteenth and eighteenth centuries

8. Agricultural revolution of the eighteenth century

9. End of the nineteenth century 

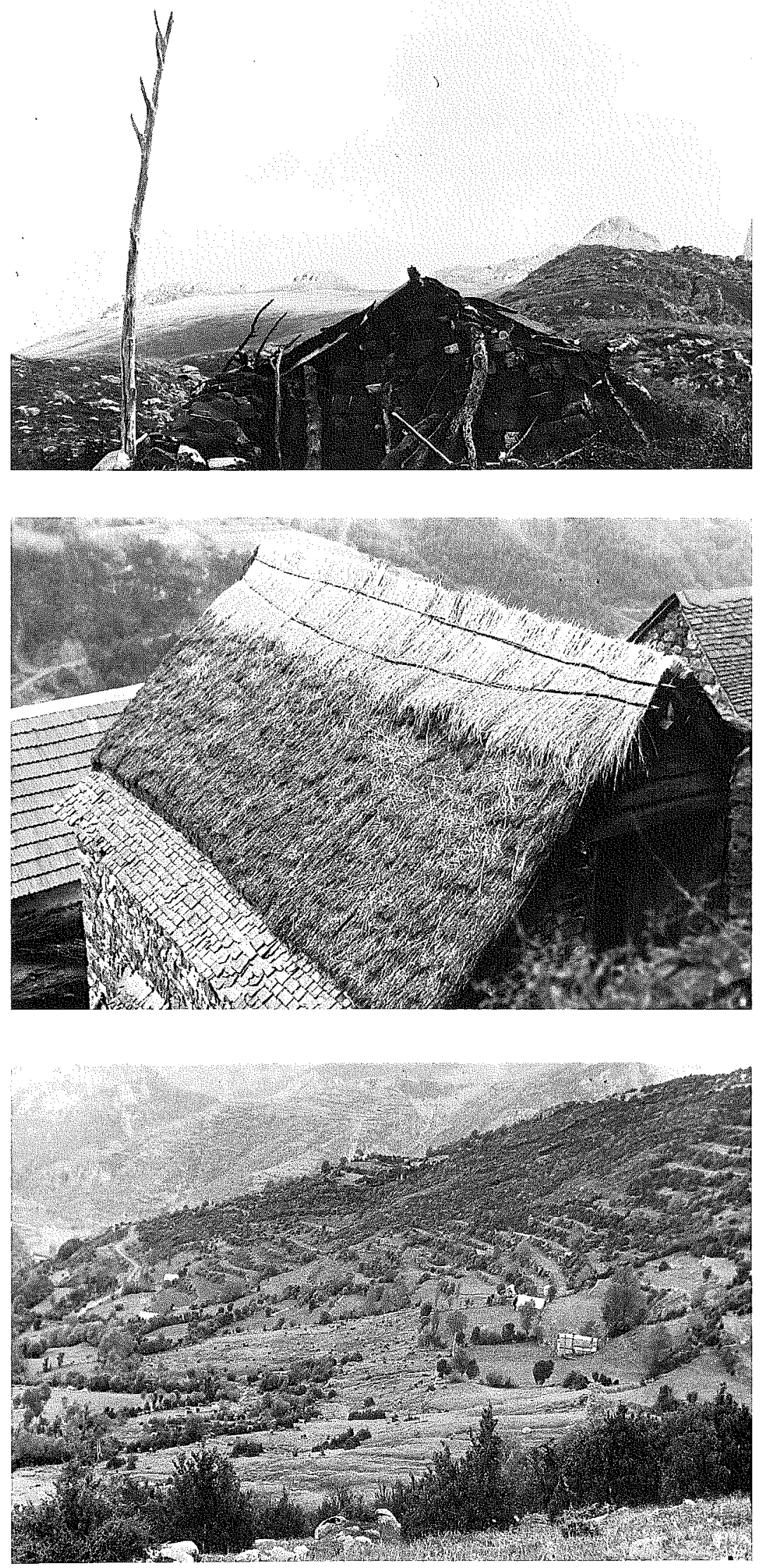

A traditional hut in the summer pastures; there is some resemblance between this pastoral hut and the dolmenic culture when human activities extended to 2,000 $\mathrm{m}$ (Rincon de Alano-Anso). Photograph by F. Fillat.

A roof of rye straw; in mountain cultures where rye was grown, as in the Pyrenees, people preserved this straw without threshing to use as roofing material (San Juan de Plan). Photograph by C. Chocarro.

A meadow landscape far from the main village with a cluster of small secondary houses; in this photograph there are private paddocks between the communal wet pastures and the steep mountain slopes (San Juan de Plan, $1,300 \mathrm{~m})$. Photograph by R. Fanlo. 
tion perished (Marin, 1985). Farm lands were abandoned, sometimes 30 percent of the total area. The number of work animals declined, although pigs were maintained and sheep, which can graze on neglected land, prospered. Land that had been cleared for cultivation reverted to forest. In some areas up to 35 percent of the villages and hamlets were totally abandoned for periods of more than twenty years (Marin, 1985).

\section{Re-Expansion between the FifteEnth and Erghteenth Genturies}

The direct consequences of the previous crises were felt until late in the fifteenth century. After that time, a slow recovery began to take effect bringing with it the establishment of a traditional model of agriculture that would eventually be consolidated by the beginning of the nineteenth century. Nevertheless, development was slower on this occasion compared to the recovery rates of earlier periods. Many small isolated settlements were not reoccupied because land close to the larger villages was preferred. There were two main types of farming: food production and the breeding of animals to be used for trading. Some high-altitude areas were reoccupied for agriculture and an expansion in the use of summer pasture occurred.

Agricultural production was related to demographic fluctuations during this period while stockbreeding developed at a more constant rate. Cattle became increasingly significant and sheep gained importance on the Ebro plains and in the mountains, although they were still linked to the nomadic cycle. The number of pigs was directly related to the population at any one time for, together with cereals and garden produce, pigs constituted 90 percent of the high-Aragonese regional diet (Marin, 1985). Work animals were used on the farms and in the forest. The European Agricultural Revolution of the eighteenth century, which preceded the Industrial Revolution, barely influenced the Pyrenean valleys although introduction of the potato was of decisive importance.

\section{DEVELOPMENT AFTER 1800}

The changes that have occurred in the nineteenth and twentieth centuries can be represented in schematic form as a series of major processes and responses that have influenced the development of different internal organizations and land-use systems; these vary in detail according to the particular characteristics of individual valleys (Figure 3). The internal balance of the system is maintained by interaction between the increase in population and introduction of new techniques which result in an increase in production and more extensive use of land that is suitable for agriculture. A community can export goods or labor and in return receive direct influx of money, or benefit indirectly through the acquisition of information and an increased demand for products. The application of different technologies with the progress of time has led to a change in the sequential use of natural resources. This is summarized schematically in Figure 4 . The most important development characteristics of these years are outlined below.

\section{The Traditional System}

This was influenced by an interchange of mares and work oxen with trading partners outside the immediate region, thus encouraging an influx of ideas and information as well as products. This is shown schematically in Figure 3 under the general heading "external influence".

From the point of view of the "internal organization" the basic location of the villages provides a number of impor-
E X T E R N A L
I N F L U E N C E
I N T E R N A L
O R R $\quad$ G
R E P L Y

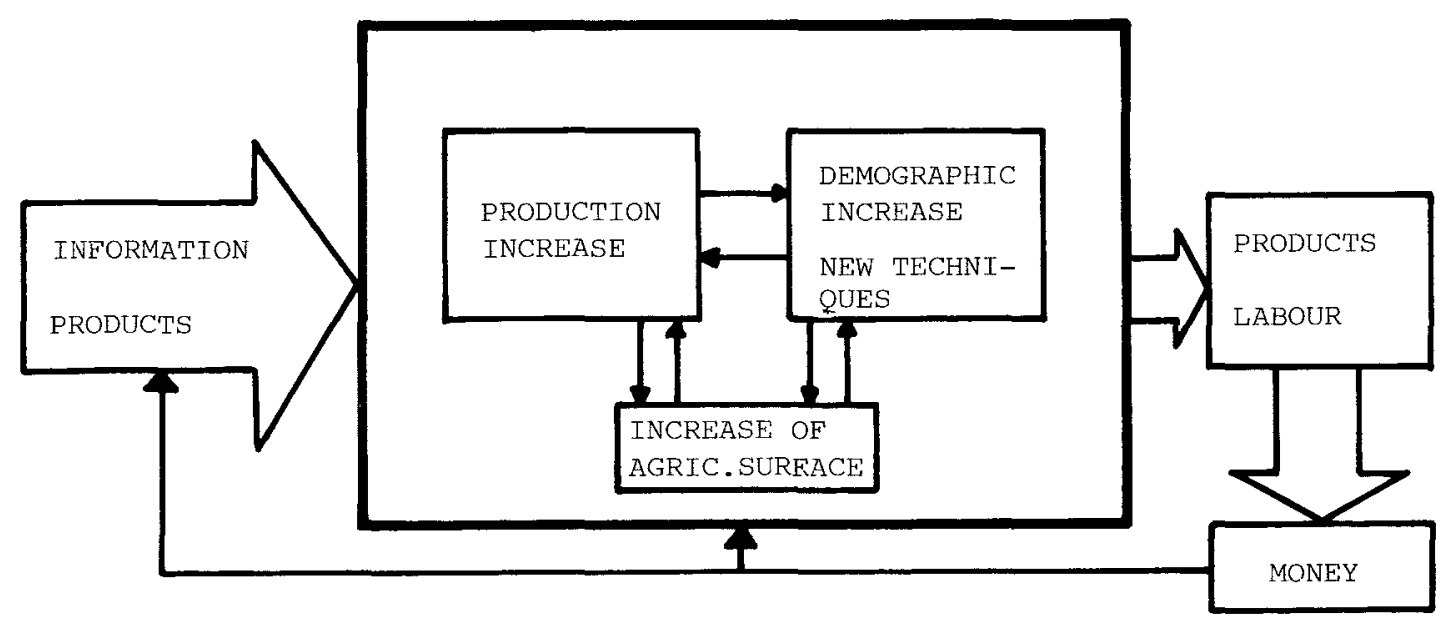

Figure 3. Schematic diagram showing the external influences, internal organization, and responses in Pyrenean valleys. 


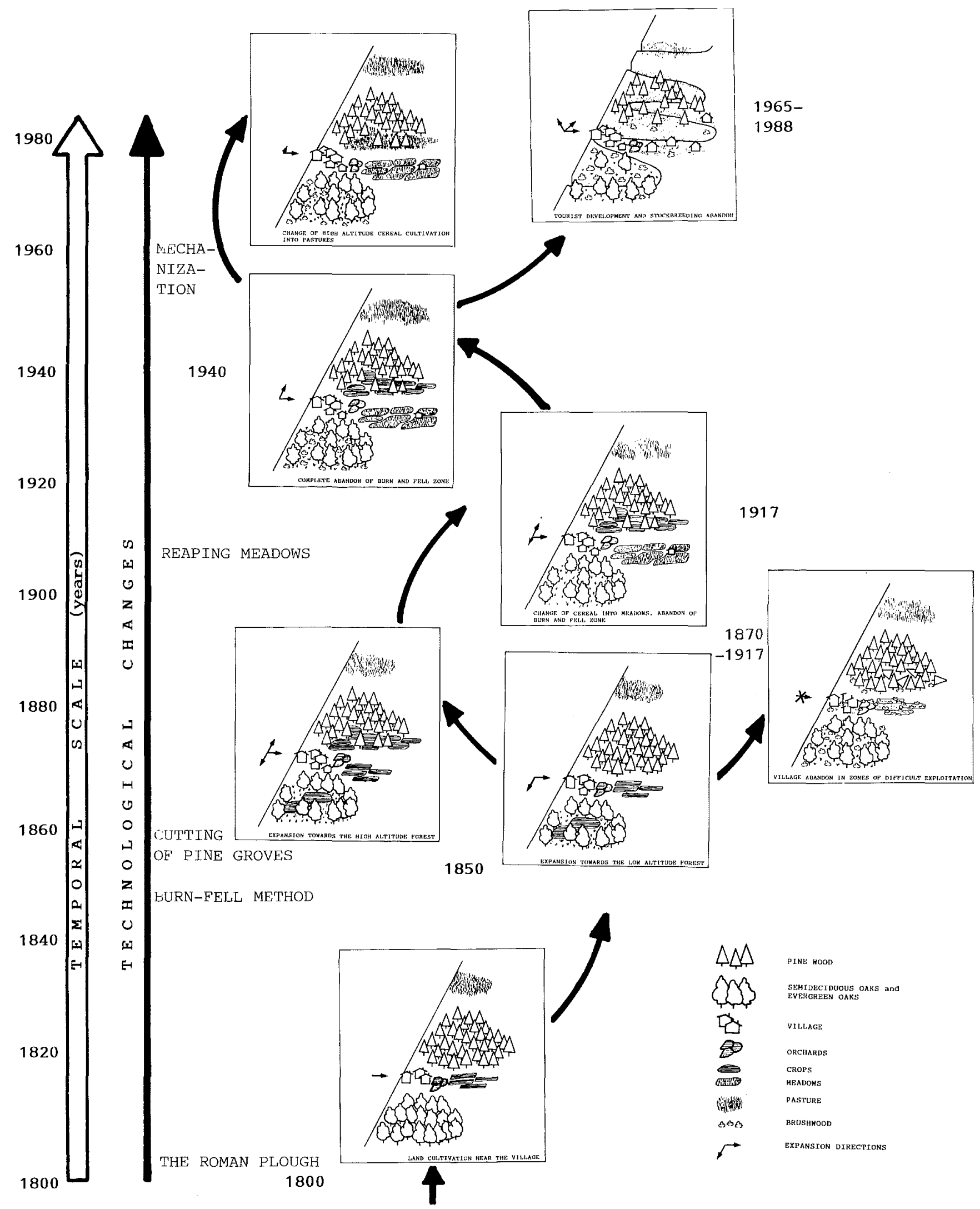

Figure 4. The sequential use of natural resources in Pyrenean valleys. 
tant insights. The location of villages depended not only on favorable agricultural land but also on sites that had maximum solar insolation and minimum risk of temperature inversion. Access to spring water was also important and water was diverted to irrigation canals along the lower valley slopes to the level of the villages. This irrigation water supported the development of vegetable gardens while cereal production (wheat) depended upon rainfed fields. A two-course rotation system began to be an important feature of cereal production in this period.

Small buildings were erected in wheat fields that were distant from the village for use in the event of storms. Sheep and goats, the most important livestock, were grazed on the stubble fields and in the forest nearest the village; in winter they were transferred to lowlands of the Ebro basin. The individual family unit was preeminent. The Roman plow was used and the cereal was cut by scythe; it was sheathed and dried in the fields, threshed by hand and winnowed; the harvested grain was then stored in individual homes. Manure was supplied by the work animals and sheep flocks. Shearing was done with a form of scissors called a "hoop". Quantitatively the monetary and material returns from this system were unimportant because it was primarily a system of subsistence.

\section{0-The Beginnings of Population Growth}

The major external influence, or input, to the Pyrenean mountain valley system was the potato. As the population increased there was a progressive encroachment on the gall oak groves of the lower levels and the landscape was transformed with the application of the slash-and-burn method of cultivation. Two successive seasons of cultivation were followed by six-to-eight years of fallow on lands that were not privately owned. This two-course rotation system persisted into the $1960 \mathrm{~s}$. Moreover, potatoes were introduced into vegetable gardens, and sheep and goat-herding extended into the slash-and-burn areas. Individual families continued to use grazing areas both at high altitudes and in the valleys, although a form of collective herding also developed. The forests provided fodder and bedding for the animals.

These developments led to the use of new technology. The traditional system of pruning, burning, and application of ashes as nutrients to the soil and the plowing of slash-and-burn which were not manured remained. The "french fork" was introduced for harvesting the potatoes which were then stored in the basements of individual houses. Looms were introduced for the first time. The beginnings of the sale of woollens in the form of surplus woollen clothing were evident at this time.

\section{0 - Period of Very High Population Density}

While some valleys did not experience their highest population densities until the early twentieth century, many reached an all time maximum in the later decades of the nineteenth century. This induced the beginnings of outmigration to distant lands, including a major flow of people to North America, especially the United States. An important external influence was the introduction of the new European strains of spring cereals, although the new
American corn production technology had little impact. The increase in population and with it the increased demand for fuel and construction wood put pressure on the forests.

The changes after 1850 influenced the internal organization structure and the land use. Some high-altitude pine forests were converted to agricultural land, the area of winter cereal at lower elevations was expanded and, closer to the villages, spring wheat and oats were planted. The slash-and-burn practices increased significantly and the potato began to serve as a major alternative to cereal. Enclosure and privatization of lands near the villages had a major visual effect on the landscape. The number of domestic animals rose in relation to the upward trend in the population density.

Agricultural practices changed gradually: work animals were used for threshing; straw was now sorted in lofts above the houses; caves were used for potato storage; and the sale of firewood to markets beyond the immediate village began to take place.

\section{7 - The First World War (Great European War)}

The war that waged across Europe had only indirect impacts in the Pyrenees. A demand for horses and mules as draft animals made itself felt and influences of the Industrial Revolution finally reached the Pyrenees.

From the point of view of the internal organization, those villages with the least favorable locations began to be abandoned, although overall the high level of population density was maintained. There was a corresponding intensification of agriculture and the cultivation of spring cereals and potatoes were extended to higher altitudes. More specialized types of buildings appeared, including the first barns used as cow stalls. Haylofts became common and the storage of hay enabled winter stabling of the animals. Specialization of resource use was accelerated, including hunting and the collection of fruits and medicinal plants.

Technological change included the introduction of new machinery, such as the silex thresher, and sawmills began to appear. Products for external markets began to multiply and included wool, meat, horses and mules, and lumber.

\section{The 1940s-The Period after the Spanish War}

Post-war requisitions and urban demands for meat had significant impacts on the Pyrenean agricultural system. The demands for laborers in the large cities acted as an additional magnet for outmigration, and the growing need for power from hydroelectricity in the Spanish core areas resulted in further pressures on the mountain lands.

Population levels began to fall after the Civil War and areas that had been subject to the slash-and-burn practices were converted to brushwood and shrub cover. Cereal production dropped, alfalfa was introduced, and the area of meadowland was extended. Potato production was greater than ever; horse, cattle, and mule breeding remained important while sheep herding declined. The production of beef now increased rapidly.

Chemical fertilizers were introduced to increase cereal production. Mechanized mowers pulled by draft animal began to appear on the valley floors wherever there were 
large fields. A system of irrigation ditches was established and associations of owners of irrigated land were set up.

\section{5 - INDUSTRIAL EXPANSION AND URBANIZATION}

The growing demands of the urban centers for meat and now, for the first time, also for milk had a major impact on mountain agriculture. Cereals for animal feed became very important and beef cattle fattened at feed-lots on the plains began to compete with mountain-raised cattle. Higher slopes were transferred into pastures and meadowland was expanded. Potato cultivation declined sharply; sheep production reached a nadir, and horse and mule breeding practically ceased. Beef and milk production were greater than ever before.

New farm technology included tractors and bailing machines and chemical fertilizers were applied to the meadowlands.

The mountain population declined in the mid-1960s to its lowest level in centuries. Outmigration to the cities was at its highest and the people began to move also to smaller cities and towns. Second homes for city dwellers began to make their appearance on the landscape in some of the mountain valleys.

\section{THE PRESENT DAY}

Today the Pyrenean valleys can be classified into three main groups:

\section{Abandoned Areas}

If recovery of village life is to be achieved, some type of alternative systems that do not aim for intensive productivity must be introduced so that an ecological equilibrium is achieved and maintained.

\section{Valleys with Tourist Potential}

Where the tourist industry is becoming the basis of the economy a balance is required between the external influence of resort development and the local cattle industry and farming practices. Perhaps of greatest importance is the need to provide the local people with a more effective role in actual policy making.

\section{REFERENCES}

Altuna, J., 1972: Fauna de mamíferos de los yacimientos prehistóricos de Guipuzcoa. Munibe, Año XXIV (1-4). 464 pp.

Bahn, P. G., 1983: Pyrenean Prehistory. Aris and Phillips Ltd., Warminster. $511 \mathrm{pp}$.

Chocarro, C., Fillat, F., Garcia-Ciudad, A., and Miranda, P., 1987: Meadows of Central Pyrenees: Floristical composition and quality. Pirineos, 129: 5-33.

Lucio, J. V., Icona, 1982: The Physical Geography Studies of the Sobrarbe. Pastures Exploitation of the Gistain Valley: Present Exploita-

\section{Cattle-Raising Areas}

Here the efficient organization of very large farms is needed to ensure maximum productivity and profit. Modern techniques, such as mechanization to replace the loss of manpower, fertilizers, and irrigation where necessary, are required.

Today Spain is a member of the European Economic Community (the Common Market). The accelerating tempo of change in this century has resulted in a serious loss of environmental stability in the Pyrenees, climaxed by massive outmigration and land abandonment, on the one hand, and extensive tourist development on the other. In addition to these factors that have had massive impacts on mountain communities, lie the extensive reforestation attempts that have produced both positive and negative results. New policies are now needed to ensure stablity of land use and the well-being of those who live in the mountain lands.

tion and Potential Capacity. Report of Forestry Service, Huesca. $803 \mathrm{pp}$.

Marin, P., 1985: La Población aragonesa en el siglo XIV y la crisis del período medieval. Revista del Instituto de Estudios Oscenses, pp. 52-108. Huesca.

Ubieto, A., 1981: Historia de Aragón: La formación territorial. Ed. Oroel. Zaragoza. $391 \mathrm{pp}$.

Vicens, J. (ed.), 1954: Atlas de Historia Universal. Barcelona. 32 pp. 